Jurnal Ekonomi Syariah Teori dan Terapan p-ISSN: 2407-1935, e-ISSN: 2502-1508. Vol. 7 No. 8 Agustus 2020: 1584-1597; DOI: 10.20473/vol7iss20208pp1584-1597

\title{
PEER TO PEER LENDING SYSTEM IN HIFDUN MAAL PERSPECTIVE: EVIDENCE FROM THE FINTECH COMPANY OF INVESTREE 1
}

\author{
Anisa Fadilah Zustika, Ana Toni Roby Candra Yudha \\ Ekonomi Syariah - Universitas Islam Negeri Sunan Ampel Surabaya \\ enenganisafz@gmail.com*, anatoniroby@uinsby.ac.id
}

\begin{abstract}
ABSTRAK
Revolusi industri 4.0 telah membawa sederet sistem yang mengena pada tata kelola kehidupan yang jauh lebih cepat, sederhana dan ringkas. Salah satu di dalamnya adalah sistem teknologi finansial (fintech). Tujuan dari studi ini adalah hendak diperolehnya sistem operasional dan implikasi fintech yang lebih pada sistem pinjaman dengan sudut pandang perlindungan harta (hifdun al maal). Studi ini menggunakan pendekatan kualitatif. Pendekatan ini dinilai layak karena mendahulukan ulasan subyektif dari informan peneltian yang mengemukakan segala wawasa, pengetahuan bahkan curahan hati pada keterlibatannya dalam sistem pinjaman dengan perusahaan fintech. Hasil studi yang didapat adalah operasional fintech belumbanyak dikenal oleh masyarakat luas. Fungsi fintek yang sama dengan perbankan namun lebih sederhana operasionalnya, menjadikannya sebuah sistem yang layak dipelajari dan dikembangkan oleh segmen bisnis, khususnya bisnis mikro dan koperasi. Hal tersebut dapat memberikan dukungan dan pelengkap dalam upaya menjaga perlindungan harta kelvarga (hifdun maal). Sehingga saran yang bersesuaian dengan ulasan pembahasan adalah perlu adanya penelitian tindak lanjut secara kuantitatif untuk mengukur kesadaran dan literasi masyarakat akan fintek, perlu adanya pendekatan dan edukasi dari otoritas tentang perbedaan dan manfaat dari fintek dan bank. Harapannya adalah manfaat dan literasi masyarakat atas produk fintek dapat terus berlanjut dan berkembang.

Kata Kunci: Fintceh, Peer To Peer Lending (P2PL), Pemeliharaan Harta
\end{abstract}

\begin{abstract}
The technology-based financial management system or so-called financial technology (fintech) has become a trend in the millennial era, both with sharia or conventional labels. This study aims to determine and examine the operational mechanisms and implications of the application of the peer to peer lending system, which is used as a transaction method both in funding and financing. The approach used is qualitative, an approach that prioritizes the subjectivity aspects of researchers and informants. The informants of this study are experts from several stakeholders such as the MUI of East Java, Masyarakat Ekonomi Syariah (MES) branch of Semarang, and 2 sharia fintech business owners and practitioners in East Java. The study results obtained are fintech based on a peer to peer lending system (P2PL) in the perspective of hifdzu mal (Investree company case study) is an online loan transaction that is consistent with the
\end{abstract}

\section{Informasi artikel}

Diterima: 26-06-2020

Direview: 20-08-2020

Diterbitkan: 25-08-2020

*Korespondensi

(Correspondence):

Anisa Fadilah Zustika

Open access under Creative Commons Attribution-Non

Commercial-Share A like 4.0

International Licence

(CC-BY-NC-SA) (C) (1)

\footnotetext{
${ }^{1}$ Artikel ini merupakan bagian dari skripsi dari Anisa Fadilah Zustika, NIM: G94216152, yang berjudul, "Financial Technology Berbasis Peer To Peer Lending Syariah dalam Perspektif Hifdzu Mal (Studi Kasus Perusahaan Investree)."
} 
theory of hifdzu maal. The suitability of the transaction with hifdul maal, because each agreement is clear and in accordance with sharia provisions such as fair, mutually committed, and protect ownership. Suggestions from this study are the need for the addition of sharia supervisory board (DPS) for fintech, collaboration with universities in business development so that literacy and inclusion of fintech can be more extensive and developed.

\section{Keywords: fintech, peer to peer lending (P2PL), protection of wealth}

\section{INTRODUCTION}

The industrial revolution 4.0 has brought the current changes significantly in Indonesia (Satya, 2018), the business and the business and lines new other (Ghufron, 2018). The change almost in all fields of the social sphere (Fitriani, 2018a), the field of education, information and technology (Baihaqi, 2018), health, economics (Yudha, Ryandono, et al., 2020), and many more. This phenomenon can be seen on the surge in internet user data and the utilization of technology in Indonesia every year (Djawahir, 2018). Based on data from the asosiasi penyelenggara Jasa Internet Indonesia (APJII) in the year 2018 stated that the population of 264,16 million such souls, there is some amount of 171,1 million or the equivalent of $64.8 \%$ (APJII, 2018).

The Data show that the growing number of internet users in Indonesia (Lenagala \& Ram, 2010). The thing that causes the appearance of increased professionalism of the business (Toni et al., 2019), breakthrough (Zaki et al., 2020), synergy (Yudha, Pauzi, et al., 2020), and the development of technology-based business or often known as financial technology (fintech) (Rusydiana, 2018).
This business has a positive impact for its users because of the ease of daily activities (Yudha \& Dusturiya, 2018). As in the field of tourism (Fitriani, 2018b), food and beverage (Elseidi, 2018), islamic banking (Sardar \& Nafik, 2016), small micro and medium enterprises (SMES) (Hamdan, 2018), and transport can be with the internet system that Go-Jek (Usman et al., 2019), in a purchase transaction there are a wide variety of e-commerce such as Tokopedia, Bukalapak, Shopee, OLX, and many more (Sari et al., 2019). Likewise in the investment and financing there is a breakthrough new Peer To Peer Lending (P2PL). All these reviews give a clear message that the industry-based fintech, need to survive all sorts of obstacles and make the most of the coming opportunities (Mohamad Akram Laldin \& Djafri, 2019). Similarly, the existence of fintech sharia in Indonesia which is already protected by the Financial Services Authority Regulation (POJK), so people who want to utilize fintech sharia and especially P2PL don't need to feel worried (Wibowo, 2016).

Peer To Peer Lending is a new platform financial transactions (Purbasari et al., 2020), which simplifies the 
intermediation function of the conventional with directly between the parties requires and the excess funds (Contreras Pinochet et al., 2019). P2PL is the development of the business model of sharing economy with technology-based (Pan et al., 2019), market-oriented in marketing the product fintech itself (Agus et al., 2019). P2PL is a collection of products and fund (crowdfunding) (Biancone et al., 2019), and also as an alternative financing (Martinez et al., 2019), which is considered complicated (Zaki et al., 2020), with the presence of P2PL financing and investment can be done easily (Mohd Thas Thaker, 2018). P2PL is the practice of investment where there crowdfunding funds for people who have the funds excessive (lenders) (Alwi, 2018), with those who require funds (borrower) (Bougatef, 2016), both SMES and individuals who made online through the gadget (smartphone, tablet, or laptop) that can be accessed without limitation of space and time (Reuters, 2018). The presence of fintech in particular P2PL is very helpful in improving the economy, especially SMES in Indonesia (El-Brassi et al., 2020).

As time goes by fintech in particular P2PL began to work together with islamic economics which is called sharia P2PL. The existence of sharia P2PL is well accepted because of the large muslim population in Indonesia (Purbasari et al., 2020). P2PL sharia implemented a system of investment and financing based on sharia principles. As one of the principles of sharia are applied this is one implementation of maqhasid sharia.

Maqasid shariah namely an effort in order to meet all the human life that prioritizes the value of benefits and to avoid from bad grades. There are 5 (five) the form of the maqasid syariah or commonly called kulliyat al - khamsah (the five general principles), which consists of hifdzul ad-din (protecting religion), hifdzun nafs (protects the soul), hifdzul 'aql (protect the intellect and the mind), hifdzun nasb (protecting offspring), and hifdzul al maal (protect the property) (Oni Sahroni in Adiwarman Karim, 2016). Hifdzul al-mal is one of the maqasid related to maintain and meet the intent and benefit will treasure. Treasure is an important element in the economy. Therefore we are obligation to developing wealth by investing. The investment is one step that aims to avoid from the attitude of hoarding treasure.

P2PL sharia is an alternative society to develop wealth with investing. P2PL sharia apply the system is based on sharia principles, especially hifdzu the mall. The reason for the chosen approach hifdzu the mall because in the transaction P2PL not the case of hoarding the treasure but rather the occurrence of the protection of property in the investment and distribution of the treasure. Where this is in accordance with the rules of the micro Islam i.e. flow concept which explains that the treasure continues to flow so that no treasure is buried. 
One of the principles of the sharia that is applied is to avoid hoarding the treasure with the investment and distribution of the treasures contained in the holy verses of SURAH. Al - Hashr verse 7 which reads:

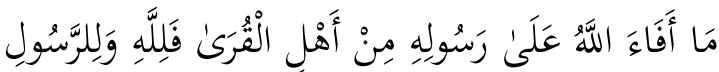

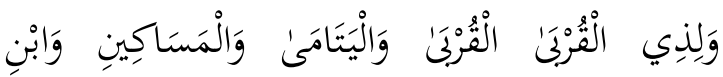

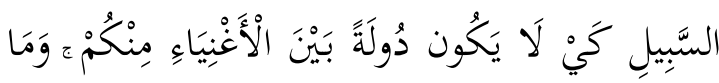

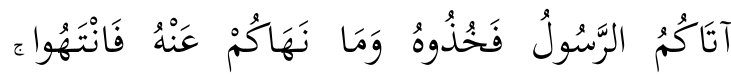

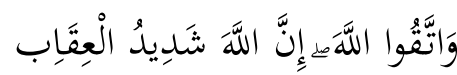

It means: "What are the spoils (fai-i) given by Allah to His Messenger (of the possessions) that is derived from the inhabitants of the cities then it is for Allah, for the Messenger, kinsfolk, orphans, poor people and people who travel, so that the treasure was not circulated among the rich people of course in between you. What the Messenger has given you, then so be it. And what is forbidding to you, then leave. And fear Allah. Indeed, Allâh is severe in punishment." (Ministry Of Religion Affair Republic Of Indonesia, 2010: 546)

In addition to the investment and distribution of the treasure on the system P2PL sharia also is applying the principles of sharia according to the contract. The contract that is used with regard to the verse above where it is relevant to the value of - the value of the verse that broadly discuss issues related to the protection of property and distribution of property. The contract is a partnership contract which includes wakalah bil contract situation, qard, musyarakah, and mudharabah depending on the agreement each party of the company.

Based on data from the FSA by May 2019 There are 113 companies P2PL in Indonesia that have been registered in the OJK and as many as 7 companies that are already licensed. Of the 7 companies that have been licensed for only 1 that is listed as part of the sharia, namely PT Investree Radhika Jaya (Investree) (OJK, 2019).

Investree is one of the companies that apply the system of sharia P2PL. This company provides the services of specialized financial services platform that utilizes technology, which aims to bring together people who have excess funds (funding) with people who need financing.

Investree operationally explain the principles applied are in accordance with sharia principles, but in its application and the transaction has not been supervised specifically of the Sharia Supervisory Board (DPS) so that the validity of islamic principles can not be guaranteed and trusted by the community. It takes a special study of whether sharia principles is in conformity with the maqasid of shariah, especially in the guarding and protection of property (hifdzu mal) which is embodied in the Qur'an, Hadith, and Islamic law other as guidelines in running the Islamic economic system.

Correspond with the review presented in the previous section, it is necessary to include a special study of the 
model fintech-based systems, peer to peer lending (P2PL) in the perspective of hifdzu mall on the Investree

\section{LITERATURE REVIEW}

Financial Technology

Financial technology (fintech) is the use of technology in the financial system that generate products, services, technology, and/or new business models as well as can have an impact on monetary stability, financial system stability, and/or efficiency, smoothness, security, and reliability of the payment system. The development of proven technology brings benefits to consumers, businesses, and the national economy, but on the other hand has potential risks which if not mitigated properly can disrupt the financial system(BI, 2017). Regulation and sources of law which regulate the course of fintech as follows:

1. UU Number 11 year 2008 about information and electronic transactions. In this UU explained that the electronic transaction is a legal act performed with the use of a computer, computer network, and/or other electronic media.

2. UU Number 8 year 1999 on consumer protection In this UU clarify that consumer protection is all efforts that ensure legal certainty to provide protection to consumers. The consumer is each person wearing the goods and/or services available in the community, both for the benefit of yourself, family, other people, and other living beings and not for trade.
3. Regulation Of Goverment Number 82 year 2012. on the implementation of systems and electronic transactions. set to carry out the provisions of UU Number 11 year 2008 about information and electronic transactions. Here is described how the implementation of system and electronic transactions in accordance with the law.

4. Regulation of $\mathrm{Bl}$ number 19/12/PBI/2017 about organizing financial technology of the Bank Indonesia regulation concerning mandatory registration in Bank Indonesia for the implementation of technology financial activities of the payment system. The obligation of such registration shall be exempted for service providers payment system who has obtained a license from Bank Indonesia and for the organizers of Financial Technology which is under the authority of other authorities. Explain that the registration is only done by institutions that have not yet signed up at $\mathrm{BI}$ and in other Authorities.

5. Reulation of OJK Number 77/ POJK.01/2016 about service borrowed money based on information technology. Explain that the service borrow borrow money based on information technology is the organization of financial services to bring together the lender with the loan recipients in order to perform the agreement of lending and borrowing 
in rupiah currency directly through the electronic system using the internet network.

6. Regulation Of OJK number 1/ POJK.07/2013 about consumer protection the financial services sector. Explained that consumer protection is the protection with the scope of the Behavior of Financial Services Businesses (PUJK).

7. Fatwa DSN MUI Number 117/DSNMUI/II/2018 about service financing technology-based information based on sharia principles. Explain that the service principle of sharia is the implementation of financial services based on sharia principles which connect between the financer through the electronic system with the help of the internet network.

The National Digital Research Centre (NDRC) declare that fintech is an innovation in the financial sector, which consists of the word "financial" and "technology" that refers to innovation in the field of financial with a touch of modern technology. There are several types of fintech in Indonesia such as Crowdfunding, peer to peer lending, emoney, insurance,P2P, Payment gateway, remittance, securities. (Gunawan,2018)

\section{Peer Po Peer Lending (P2PL)}

Peer to peer lending (P2PL) is one form of fintech where understanding P2PL is the scheme of the financial services that bring together the lender and recipients of loans online (Sikapi,2019P2PL regulated on POJK No. 77/ POJK.01/2016 About Service
Borrowed Money Based on Information Technology that menjelasakna that service borrowed Money Based on Information Technology is the implementation of financial services to bring together the lender with the loan recipients in order to perform the agreement of lending and borrowing in rupiah currency directly through the electronic system using the internet network. The understanding of the P2PL according to the OJK is Peer To Peer Lending are the practice of borrow and give loans online through a container called platform. The Platform itself is the container that brings together many people who need a loan with a lot of other people who are willing to provide the loan. Where can be concluded that the P2PL (online loan) is a transaction of lending and borrowing done through platforms that bring together people who have surplus funds (lenders) with people who lack the funds (the borrower) is carried out using information technologybased internet (smartphone, tablet, computer, laptop, notebook) that can be done anywhere and anytime.

\section{Hifdzul mal}

\section{Understanding of Hifdzu Mal}

Islam regulates all activities in the life of one of them about the treasure. In maqhasid sharia there are five general principles (kulliyat al -khamsah), namely hifdzu din, hifdzu nafs, hifdzu aql, hifdzu the mal, and hifdzu nasl (Oni \& Adiwarman, 2019). Hifdzu mal can be interpreted as protection of property. Maintain and meet 
the intent of the will treasures can be viewed from the side of how to get it (min janibi al - wujud) or from the sides kept the property that is already owned ( min janibi al- 'adam).

The treasure called the al - mal or the plural al - anwal. Literally, property (al - mal) is malaktahu min kulli sya'i (treasure is everything you have). In Termologis, treasure can be defined as something which is utilized in the pekara that are legal according to syara' (Islamic law), such as business, loans, consumption, and endowments (administration)

(Mardani,2015). Based on the description above can be drawn the conclusion the treasure is one of the core needs in life, the human will not be able to separate from him. Therefore, the treasure must be preserved and protected in accordance with the Islamic principles contained in the hifdzu the mal.

\section{Hifdzu Mal in the Maqasid Mandate}

Hidzu mal is translated into the maqasid ammah (general objectives) and maqahid khassah (special purpose). In this explanation only explains the related maqasid ammah. Maqasid ammah is the goal prescribed some collection of law or traffic law. As for the specific provisions of the maqasid ammah. The Table below describes the ten elements in the maqasid ammah which will be associated with hifdzu the mal.

Table.1

Provisions of the maqasid ammah

\begin{tabular}{|l|l|l|}
\hline Number & $\begin{array}{l}\text { The terms of the } \\
\text { maqasid ammah }\end{array}$ & Description \\
\hline 1. & $\begin{array}{l}\text { The agrement } \\
\text { must be clear }\end{array}$ & $\begin{array}{l}\text { Every agreement } \\
\text { business should be }\end{array}$ \\
\hline
\end{tabular}

\begin{tabular}{|c|c|c|}
\hline & & $\begin{array}{l}\text { clearly known by the } \\
\text { parties to the } \\
\text { contract so as not to } \\
\text { cause a dispute } \\
\text { between them }\end{array}$ \\
\hline 2. & Fair in trade & $\begin{array}{l}\text { This principle can be } \\
\text { interpreted that the } \\
\text { whole process of } \\
\text { economic activity } \\
\text { must be based on } \\
\text { religious law. }\end{array}$ \\
\hline 3. & $\begin{array}{l}\text { Commitment by } \\
\text { agreement }\end{array}$ & $\begin{array}{l}\text { Economic activities } \\
\text { should be based on } \\
\text { the commitment and } \\
\text { agreement business }\end{array}$ \\
\hline 4. & $\begin{array}{l}\text { Protect } \\
\text { ownership }\end{array}$ & $\begin{array}{l}\text { The Ulama are } \\
\text { agreed all activities } \\
\text { taking other people's } \\
\text { property by way of } \\
\text { vanity is haram }\end{array}$ \\
\hline 5. & $\begin{array}{l}\text { The provisions of } \\
\text { the sharia } \\
\text { contract }\end{array}$ & $\begin{array}{l}\text { The contract must be } \\
\text { in accordance } \\
\text { conditions pillars and } \\
\text { requirements. } \\
\text { According to the } \\
\text { scholars of the pillars } \\
\text { of the marriage } \\
\text { contract consists of } 3 \\
\text { elements, namely } \\
\text { sighat (ijab and } \\
\text { qabul), aqidan (the } \\
\text { two parties who } \\
\text { make the contract) } \\
\text { and ma'qud alai } \\
\text { (object of contract). }\end{array}$ \\
\hline 6. & $\begin{array}{l}\text { The treasure } \\
\text { should be } \\
\text { distributed }\end{array}$ & $\begin{array}{l}\text { In Islam prohibited the } \\
\text { hoarding of treasure } \\
\text { to prevent economic } \\
\text { inequality. }\end{array}$ \\
\hline 7. & $\begin{array}{l}\text { The obligation to } \\
\text { Work and } \\
\text { produce }\end{array}$ & $\begin{array}{l}\text { This context explains } \\
\text { that the search for } \\
\text { sustenance becomes } \\
\text { a liability to provide } \\
\text { for the needs of } \\
\text { treasure, because if } \\
\text { we don't perhaps get } \\
\text { money and treasure }\end{array}$ \\
\hline 8. & $\begin{array}{l}\text { Investment } \\
\text { Treasure }\end{array}$ & $\begin{array}{l}\text { Islam encourages US } \\
\text { to develop the } \\
\text { property and prohibit } \\
\text { the hoard of treasure }\end{array}$ \\
\hline 9. & $\begin{array}{l}\text { Investment with } \\
\text { mudharabah } \\
\text { contract }\end{array}$ & $\begin{array}{l}\text { Recommended } \\
\text { working together to } \\
\text { get profit }\end{array}$ \\
\hline 10. & $\begin{array}{l}\text { The balance } \\
\text { between profit } \\
\text { and risk }\end{array}$ & $\begin{array}{l}\text { This concept explains } \\
\text { that keuntungn on } \\
\text { capital is legitimate } \\
\text { obtained the owners } \\
\text { of capital who have } \\
\text { been facing the risk } \\
\text { of capital }\end{array}$ \\
\hline
\end{tabular}

Sumber : Oni Sahroni \& Adiwarman Karim, 2016, Maqashid Bisnis \& Keuangan Islam, PT Raja Grafindo Persada.

III. RESEARCH METHODS

\section{Research approach}


The research approach used in the study is qualitative. The approach is technical and the methods used in the research is the exploration of the casuistic because in accordance with the topic of the problems raised. Qualitative research is very different to the quantitative approach which tends to be generalised and is dominated with the pattern of deductive, approach to this is to use the understanding and insights the informants elaborated with the context of the research that the heart is lifted.

\section{The type and Source of data}

Data Sources used in the research use the summer data and the secondary. the source of primary data comes from the customer service (CS) Investree, academic, actors fintech, and the user Investree. Secondary sources on the study of Berli comes from books, journals, articles, and/or data derived from the website.

\section{Data Collection techniques}

This research uses qualitative research where the research using a variety of ways to get as well as collect data with clear, specific, and deep. Data collection techniques used in this research is observation (directly to the related companies), interviews (conduct interviews with the parties concerned such as customer service (CS) Investree, academic, actors fintech), documentation (take the data based on the document important documents, announcements, newspaper, award writing).

\section{Data Processing techniques}

Data processing techniques performed in this research is by way of:

1. Editing

Checking back related to the validity of the data that have been collected in the field.

2. Organizing

The preparation of the return data which is then clarified according to the need for enabling research.

3. Analyzing

The processing of the last data required by the researcher to answer the problem formulation.

\section{Data Analysis techniques}

Data analysis techniques in this study using the water method methods offered by Miles and Huberman is to perform 3 activities of analysis simultaneously, namely data reduction, presentment of data, retraction conclusions (wiley, 2013). Here's the explanation:

1. Data reduction

Doing a survey back from all the data obtained from the field by doing the selection and simplification, then transform in terms of its completeness as well as to align between the data obtained with the relevance of the research.

2. Presentation of data

compiling the relevant data according to the framework of the presentation that has been planned with the formulation of the problem so that the information obtained will be 
easy to answer the problem in a research.

3. retraction of conclusion

compiling the relevant data according to the framework of the presentation that has been planned with the formulation of the problem so that the information obtained will be easy to answer the problem in a research.

\section{RESULTS AND DISCUSSION}

In the maintenance of the property, every person has the right to keep his property. Islam also respects the possessions of the muslims. Based on the results of interviews with 7 informants then, 5 people, which states the interconnectedness of hifdzu malls in transactions with the following results: Any Agreement should clearly

Table 2.

P2PL Perspective Hifdzul Mal

\begin{tabular}{|c|c|c|c|}
\hline No & Informant & result & \multirow{6}{*}{$\begin{array}{l}\text { Analysis result } \\
\text { ased on the } \\
\text { results from a } \\
\text { variety of } \\
\text { informants, } \\
\text { then the results } \\
\text { of the analysis } \\
\text { of the } \\
\text { research on } \\
\text { P2PL in the } \\
\text { perspective of } \\
\text { Hifdzu Mall, } \\
\text { among others, } \\
\text { not the } \\
\text { accumulation } \\
\text { of possessions } \\
\text { that are } \\
\text { prohibited by } \\
\text { the religion of } \\
\text { Islam, which is } \\
\text { in the } \\
\text { transaction } \\
\text { P2PL no no } \\
\text { hoarding by } \\
\text { treasure by } \\
\text { the organizers } \\
\text { where the } \\
\text { fund is - really } \\
\text { directly given } \\
\text { to the needy if } \\
\text { the parties }\end{array}$} \\
\hline 1. & Sandra & $\begin{array}{l}\text { Transactions } \\
\text { are } \\
\text { guaranteed } \\
\text { and secure , } \\
\text { no hoarding } \\
\text { the treasure, } \\
\text { and easy } \\
\text { transaction }\end{array}$ & \\
\hline 2. & $\begin{array}{l}\text { Ust. Dian } \\
\text { Berkah }\end{array}$ & $\begin{array}{l}\text { No idl } \\
\text { (hoarding } \\
\text { treasures) in } \\
\text { the transaction }\end{array}$ & \\
\hline 3. & Pak Z & $\begin{array}{l}\text { Treasure is } \\
\text { distributed so } \\
\text { that it can } \\
\text { drive the } \\
\text { economy }\end{array}$ & \\
\hline 4. & $\begin{array}{l}\text { Pak Adrial } \\
\text { Siaril }\end{array}$ & $\begin{array}{l}\text { Safe and easy } \\
\text { investing }\end{array}$ & \\
\hline 5 & Pak Hury & $\begin{array}{l}\text { hifdzu mal if } \\
\text { the } \\
\text { management } \\
\text { of the treasure } \\
\text { according to } \\
\text { islamic } \\
\text { principles }\end{array}$ & \\
\hline
\end{tabular}

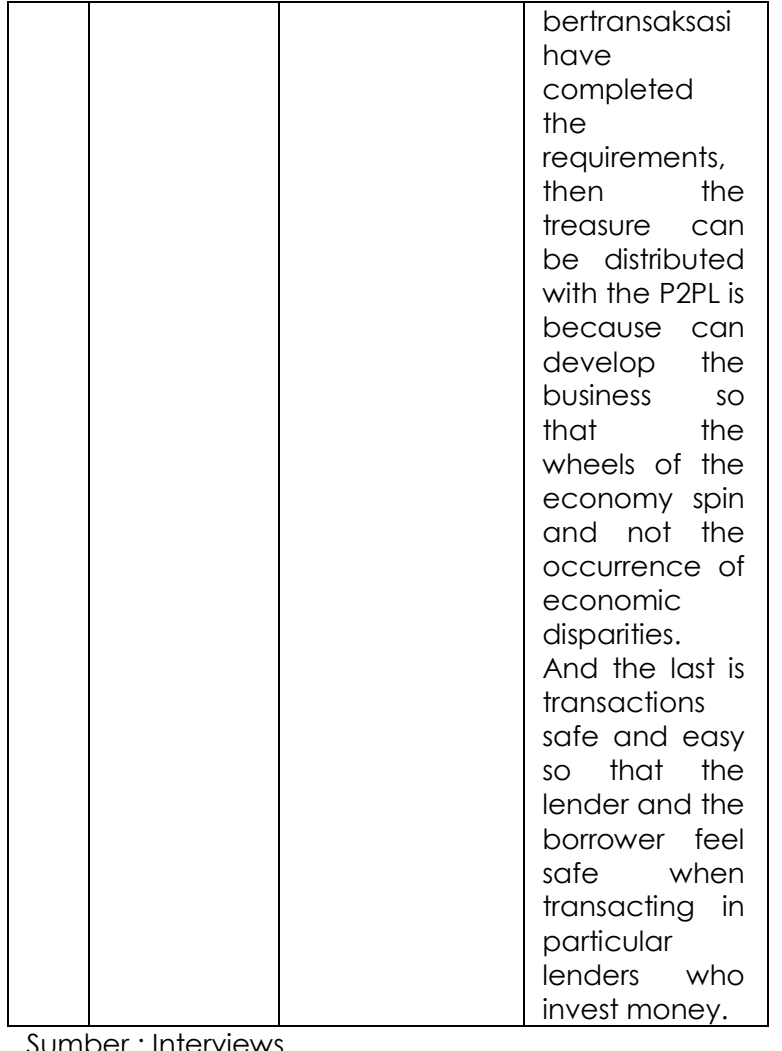

In addition to the above data there are also some supporting data related hifdzu mall Investree submit all funds fines (100\%) for social activities.

\section{Maqashid Ammah}

Maqasid ammah is a translation of the hifdzu the mall. Which of the maqasid ammah is the purpose it is prescribed to offer some collection of law or traffic law. The following provisions of the maqasid ammah dam implementation on the investree company:

1. The agreement must be Clear

in this case explain that the business deal should be known by both parties are committed so as not to dispute. The people who committed should be of mutual blessing and love like no one didzalimi. In this case it is applied by Investree through transaction transparent which lenders as the 
people who fund reserves the right to choose who will be given financing. So there is no keterpaksanaan and funded with the blessings according to the will and taste of the liver lenders.

\section{Fair in trade}

The principle of justice this is an economic activity that is based on religious law. Where this justice was created so as not to imbalance the economy. The principle of justice can be specialized in activities of mutual help. As for the principle of justice, namely Investree as company help people who need funds (borrower) and the person that surplus funds (lenders) to help each other.

3. Commitment by agreement

The commitment in the agreement referred to is the commitment between the participants in the transaction activity. In Investree commitment agreement between the borrower with the lenders asked in a statement where if we agree to all these terms then we have already committed to obey all the terms and conditions applicable.

\section{Protect ownership}

This principle is the principle of the need to protect the ownership and prohibited from taking the property of another person. Based on the research data one of lenders Adrian Siaril stated that the transactions carried out in the Investree is safe therefore he chose to invest in
Investree. Not only that in Investree also explained that there is an increase given to the marketplace and lenders so that the transactions really transparent so there is no taking of property of another person.

5. The provisions of the sharia contract The contract in question here is the ijab - qabul in the contract against a matter where the contract must be in accordance with the tenets and terms are shigat, both parties perform the contract, and the object of the contract. Likewise, the principles of akad should be applied, i.e. transparency, ease, voluntary, keeping promises, mutual benefit, based on the cause of halal. Based on the research in P2PL on Investree applying Al - Qard contact (debt receivable) and contract of Wakalah Bil Situation (the representative) who has in accordance with the provisions of sharia.

6. The treasure should be distributed In islam prohibited the hoarding harat to prevent the occurrence of economic inequality therefore the treasure should be distributed. Investment is one of the distribution of the treasure which we help people who need the treasures. P2PL in addition to providing facilities for investing also provides facilities for distributing treasure with a way of helping those who need financing. Based on the research data Investree is a marketplace to distribute the 
treasure in addition to it does not happen hoarding treasures in the transaction because the transaction is directly given to people in need of funds when they have completed all the applicable terms and conditions.

7. The obligation to Work and produce These points explain that the search for rincome be an obligation to provide the needs of the treasure, because if it doesn't work we may not get benefit to. The implementation of these points in the transaction P2PL in Investree that Investree as the organizer of the transaction works to help borrower and lenders so that the Investree entitled to benefit from the business derived from the situation.

8. Investment Treasure

It means is an effort to expand into the treasure and hoard treasure. Based on the results of the study P2PL provide facilities for the lenders to invest her fortune more easy and safe. One of the lenders Adrian Siaril also invest to avoid inflation.

9. Investment with mudharabah contract

This investment is recommended to work together for the benefit. In the transaction P2PL in Investree not use will mudharabah but rather using the contract of Al - Qard (debt) and Wakalah bil Increase (representatives) so that is not a partnership contract but rather a contract please help. However, after having analyzed more in depth stated that the transaction uses mudharabah muqlatoh contract which manager free capital in managing its business.

10. The balance between profit and risk The balance between profit and risk what is meant is the owner of capital is entitled to benefit because the risk of their capital. It is applied in P2PL in Investree which lenders are entitled to get an increase from the organizers because it helps in finance the borrower.

\section{v. CONCLUSION}

Conclusion based on the analysis the author of the financial technology (fintech) - based systems, Peer To Peer Lending (P2PL) in the perspective of hifdzu mall on the company Investree. Transactions P2PL in the company Investree considered in accordance with the perspective Hifdzu Mal lestate maintenance) which includes: no hoarding treasure, invested with secure, property distributed according to the rules of sharia. It can be see of the transaction, the product, and the contract that is applied by Investree. Transactions P2PL in Investree also in accordance with the provisions of the maqasid ammah, which include: "the agreement must be clear, fair in trade, a commitment by agreement, protect ownership, the provisions of the sharia contract, the treasure should be distributed, the obligation to work and produce, investment Treasure, investment with mudharabah contract, the balance between profit and risk". However at 
points the investment with mudharabah contract is not in accordance with what happens in Investree because Investree using the contract of $\mathrm{Al}$ - Qard and Wakalah Bil Situation-based help is not a contract of cooperation.

There are 2 technical advisor sharia business tasked with providing input and help Investree sharia in running the business in accordance with sharia principles recommended by the DSN-MUI in accordance with the letter of recommendation received. Where 2 the technical advisor is as a replacement DPS.

\section{BIBLIOGRAPHY}

Abdus Salam, wawancara, 8 Agustus 2019 Adrian Siaril Wawancara, 29 Oktober 2019

Alwi, A. B. (2018). Pembiayaan berbasis teknologi informasi (fintech) yang berdasarkan syariah. Al-Qānūn, 21 (2), 255-271. https://katadata.co.id/berita/2017/ $08 / 28 / \mathrm{bi}-$

Baihaqi, J. (2018). Financial technology peer-to-peer lending berbasis syariah di indonesia. Tawazun: Journal of Sharia Economic Law, 1(2), 116-132. DOI: http://dx.doi.org/10.21043/tawazun .v1i2.4979

Biancone, P. Pietro, Secinaro, S., \& Kamal, M. (2019). Crowdfunding and fintech: Business model sharia compliant. European Journal of Islamic Finance, 12, 1-9. DOI: https://doi.org/10.13135/2421$2172 / 3260$

Bougatef, K. (2016). How corruption affects loan portfolio quality in emerging markets? Journal of Financial Crime, 23(4), 769-785. https://doi.org/10.1108/JFC-042015-0021

Contreras Pinochet, L. H., Diogo, G. T., Lopes, E. L., Herrero, E., \& Bueno, R. L. P. (2019). Propensity of contracting loans services from FinTech's in Brazil. International Journal of Bank Marketing, 37(5),
1190-1214.

https://doi.org/10.1 108/IJBM-072018-0174

Djawahir, A. U. (2018). Teknologi-layanan Kevangan, Literasi-inklusi Keuangan, dan Value pada Fintech Syariah di Indonesia: Perspektif S-O-R (Stimulus-organismresponse) Model. 2nd Proceedings Annual Conference for Muslim Scholars, April 2018, 439-448. www.bi.go.id/diakses

El-Brassi, M. A. M. A. , Alhabshi, S. M., \& Othman, A. H. A. (2020). Exploring the Knowledge of Islamic Banking Among Libyan Bankers. International Journal of Islamic Economics and Finance (IJIEF), 3(1), 1-20. https://doi.org/10.18196/ijief.2119

Elseidi, R. I. (2018). Determinants of halal purchasing intentions: evidences from UK. 9(1), 167-190. DOI: https://doi.org/10.1 108/JIMA-022016-0013

Fitriani, H. (2018a). Kontribusi fintech dalam meningkatkan keuangan inklusif pada pertanian (Studi analisis melalui pendekatan keuangan syariah dengan situs peer to peer lending pada pertanian di Indonesia). El-Barka: Journal of Islamic Economics and Business, $1(1)$, 1-26. https://doi.org/10.21 154/elbarka.v1 i1. 1392

Fitriani, H. (2018b). Proyeksi potensi pengembangan pariwisata perhotelan dengan konsep syariah. Muslim Heritage, 3(1), 4160.

https://doi.org/10.21 154/muslimheri tage.v3il.1257

Ghufron, M. A. (2018). Revolusi industri 4.0: Tantangan, peluang dan solusi bagi dunia pendidikan. Seminar nasional dan diskusi panel multidisiplin hasil penelitian dan pengabdian kepada masyarakat.

Hamdan, H. (2018). Industri 4.0: Pengaruh revolusi industri pada kewirausahaan demi kemandirian ekonomi. Jurnal Nusantara Aplikasi Manajemen Bisnis, 3(2), 1-8. https://doi.org/10.29407/nusamba. v3i2.12142 
Lenagala, C., \& Ram, R. (2010). Growth elasticity of poverty: Estimates from new data. International Journal of Social Economics, 37(12), 923-932. DOI:

https://doi.org/10.1108/0306829101 1083008

Martinez, L. B., Scherger, V., \& Guercio, M. B. (2019). SMEs capital structure: trade-off or pecking order theory: a systematic review. Journal of Small Business and Enterprise Development, 26(1), 105-132. DOI: https://doi.org/10.1108/JSBED-122017-0387

Mohamad Akram Laldin, \& Djafri, F. (2019). Islamic Finance in The Digital World: Opportunities and Challenges (Kewangan Islam dalam Dunia Digital: Peluang dan Cabaran). Journal of Islam in Asia, 16(3), 283299.

DOI: https://doi.org/10.31436/jia.v16i3.85 3

Mohd Thas Thaker, M. A. Bin. (2018). A qualitative inquiry into cash waqf model as a source of financing for micro enterprises. ISRA International Journal of Islamic Finance, 10(1), 19-35. DOI: https://doi.org/10.1 108/IJIF-07-20170013

Pan, X., Dresner, M., \& Xie, Y. (2019). Logistics IS resources, organizational factors, and operational performance: An investigation into domestic logistics firms in China. International Journal of Logistics Management, 30(2), 569-594. DOI: https://doi.org/10.1 108/IJLM-022018-0023

Purbasari, L. T., Sukmana, R., \& Ratnasari, R. T. (2020). Efektivitas zakat, infaq dan shadaqah dalam mengentaskan kemiskinan di indonesia: menggunakan teknik basic needs deficiency index. 7(2), 222-233.

https://doi.org/10.20473/vol7iss2020 2pp222-233

Reuters, T. (2018). State of Global Islamic Economy Report 2018/19. In Dubai International Financial Centre.

Rusydiana, A. S. (2018). Developing Islamic financial technology in Indonesia.
Hasanuddin Economics and Business Review, 2(2), 143-152. DOI: https://doi.org/10.26487/hebr.v2i2.1 550

Sardar, Z., \& Nafik, M. (2016). Kesejahteraan dalam perspektif islam pada karyawan bank syariah. Jurnal Ekonomi Syariah Teori dan Terapan, 3(5), 394-395.

Sari, F. K., Safitri, N., \& Anggraini, W. (2019). Persepsi, sikap dan minat pariwisata halal di Daerah Istimewa Yogyakarta. Ihtifaz: Journal of Islamic Economics, Finance, and Banking, 2(2), 137. DOI:

https://doi.org/10.12928/ijiefb.v2i2.8 57

Satya, V. E. (2018). Kajian singkat terhadap isu aktual dan strategis strategi Indonesia menghadapi industri 4.0. Pusat Penelitian Badan Keahlian DPR RI.

Toni, A., Candra, R., Sunan, U. I. N., \& Surabaya, A. (2019). Measuring professionalism in zakat management institution in East Java. KnE Social Sciences, 3(11), 903-914.

DOI: https://doi.org/10.18502/kss.v3i 11.4 058

Usman, H., Sobari, N., \& Sari, L. E. (2019). Sharia motivation in Muslim tourism definition, is it matter? Journal of Islamic Marketing, 10(3), 709-723. https://doi.org/10.1108/JIMA-012018-0015

Wibowo, B. (2016). Analisa regulasi fintech dalam membangun perekonomian di indonesia. Jurnal Magister Teknik Elektro Universitas Mercu Buana, 1-9.

Yudha, A. T. R. C., \& Dusturiya, N. (2018). Model pengembangan kewirausahaan sosial berbasis mahasiswa pada lembaga amil zakat. El-Qist, 8(1), 1618-1637.

Yudha, A. T. R. C., Pauzi, N. S., \& Azli, R. binti M. (2020). The synergy model for strengthening the productivity of Indonesian halal industry. 4(2), 186-199. https://doi.org/10.26740/aluqud.v4n2.p186-199

Yudha, A. T. R. C., Ryandono, M. N. H., Rijal, A., \& Wijayanti, I. (2020). 
Zustika, et al/Jurnal Ekonomi Syariah Teori dan Terapan Vol. 7 No. 8 Agustus 2020: 1584-1597

Financing model to develop local commodity business of East Java in Maqashid Syariah perspective. Test Engineering and Management, 83(3590), 3590-3595.

Zaki, I., Widiastuti, T., Yudha, A. T. R. C.,
Wijayanti, I., \& Mi'raj, D. A. (2020). Implementation of Islamic entrepreneurial culture in Islamic boarding schools. International Journal of Innovation, Creativity and Change, 11 (11), 452-469. 